\title{
Regeneration of Inorganic Nutrients from Diatom Decomposition*
}

\begin{abstract}
Akiyoshi KamataNI**
Abstract: The regeneration of the inorganic nutrients (phosphorus, nitrogen and silicon) from diatom kept in the dark place while subjected to bacterial attack was studied, using three kinds of species: $S$. costatum, $T$. decipiens and $C h$. gracilis. The regeneration processes were, generally speaking, divided into four stages. The active mineralization of diatom appeared to have been restricted to the 2nd stage, which was regulated by physiological characters, species of diatom, and also the temperature condition under which the sample was kept.

The resolution of silica wall and the consumption of organic carbon get earlier than the regeneration of phosphorus and nitrogen. Hence, the ratio of $\mathrm{Si}: \mathrm{P}$ showed typically high value at the early time, but as the mineralization went on the ratio was gradually decreased and approached to the value which the diatom had at initial. Meanwhile, the N:P ratio maintained nearly, constant value and was close to the ratio of the starting sample. These ratios undergo a change succesively in the course of mineralization, but, seem to be regulated by the physiological characters and temperature condition. The solubility of silica frustules are finally discussed.

It was inferred from the present examination that the stoichiometrical relation between oxygen consumption and regeneration of inorganic phosphorus and nitrogen, which was developed by REDFIFLD (1934) and RICHARDS (1958) for the relative distribution of nitrate, phosphate and silicate in the sea was not to be materialized at early stage of mineralization.
\end{abstract}

\section{Introduction}

The distribution and annual cycle of inorganic elements, which are concerned to the biological circulation, had been observed all over the oceans by many workers. In addition to these observations, it was certified that the composition of these elements was very similar to that of plankton. The average ratios assembled by FLEMING (1940) has been used as a basis for evaluating the biological circulation in the sea. On the other hand, it has been demonstrated repeatedly in culture experiments that the elementary composition of plankton can be varied by changing the composition of the medium in which they grew (KETCHUM and REDFIELD, 1949; KAMATANI, 1968).

The mineralization processes for silicon, nitrogen and phosphorus in plankton have been studied individually by several workers (COOPER, 1937; VON BRAND et al., 1937-47; JORGENSEN, 1955;

* Received December 6, 1968

** Tokyo University of Fisheries
LEWIN, 1961), but only GRILL and RICHARDS (1964) has studied them simultaneously. It is regrettable that they had not paied much attention to the species and physiological conditions in which they used plankton community.

The purpose of this paper is to report the experimental results of the simple case of mineralization process, as regards with its species and physiological properties of plankters cultured under controlled laboratory conditions.

\section{Experimental procedure}

The phytoplankton, Skeletonema costatum (GREVILlE) ClEVE, was used for the first experiments, which were pure culture but not completely bacteria free. The phytoplankton was cultured with natural sea water collected from Matsushima Bay. The sea water was filtered through a tightly packed plug of cotton wool and sterilized by autoclave at $100^{\circ} \mathrm{C}$ for about $30 \mathrm{~min}$., then cooled at room the sterilized sea water was enriched with inorganic nutrients, trace elements and vitamin $B_{12}$. The plankton 
was cultured with the enriched sea water in a cabinet thermostated at $20^{\circ} \pm 3^{\circ} \mathrm{C}$, equipped with a light system such as daylight type fluorescent tube which gave a total illumination of about 5,000 lux. The amount of inorganic nutrients added to the medium was regulated to a such suitable concentration that the plankton could be able to consume almost entirely within about 7 days under the above mentioned temperature and light conditions. One or two days later the inorganic nutrients were exhausted by the plankton, then the sample was transferred into a polyethylene bottle covered with a sheet of black polyethylene, and kept in a dark thermostated cabinet. After darking, the sample had been shaked vigorously for every day, so as to keep an aerobic condition during the experimental period.

In order to determine the inorganic nutrients regenerated by plankton, decomposing in the dark system, subsamples were withdrawn at intervals through a type of millipore filter with a $0.8 \mu$ pore size. The filtrate then was taken in polyethylene bottle and stored in a refrigerator until convenient numbers had been collected for analysis. The filtrate was used for the determination of nitrate, nitrite, phosphate and silicate.

Inorganic phosphate was determined colorimetrically by the method reported by MURPHY and RILEY (1962) and total phosphate by the method of MENZEL and CORWIN (1965). Eight $\mathrm{m} l$ of 5 per cent potassium persulfate was directly added to a $50 \mathrm{~m} l$ of the sample and the mixture was digested for 60 minutes on a steam bath at $100^{\circ} \mathrm{C}$. The inorganic phosphate released was determined by the method as discribed above. The content of phosphorus in the plankton was estimated as the difference between total phosphorus and inorganic phosphorus.

The unfiltered sample was submitted to distillation under alkaline condition with $\mathrm{MgO}$, the distilled off ammonia was captured in diluted sulfuric acid solution, and the solution was submitted to the analysis of ammonia by the colorimetric method by NESSLER. Total organic nitrogen was determined by a micro-Kjeldahl procedure using $\mathrm{HgO}$ as catalyst.

Nitrite was determined by the modified method of the Geiss-Ilosvey procedure currently used by
Japanese oceanographers. Nitrate was determined by the method of MORRIS and RILEY (1963) who reduced nitrate to nitrite by the use of a reductor column with amalgamated cadmium fillings.

The soluble silicate appearing in the medium was determined by the silicomolybdate, yellow colorimetric method, using the same techniques as ROBINSON and THOMPSON (1948). In this case, the salt effect on the color development was corrected, providing 1.15 factor for the salt error. For the analysis of silicate in plankton, the particulate silicate was collected by filtration using a millipore filter with a $0.8 \mu$ pore size, and the collected sample was fussed with a mixture of anhydrous sodium carbonate and potassium carbonate in platinum crucible, so as to convert the silicate into a soluble form. The fused silicate was dissolved in distilled water, neutralized with $2 \mathrm{~N}$ sulfuric acid, and finally filled up to a suitable volume. In order to avoid silicate contamination from glass bottle, distilled water kept in polyethylene bottle was used for the silicate analysis.

For the determination of organic carbon in the plankton and its residue, those matters were collected on a Whatman GFC glass filter by filtration, and the filter was put into a combustion tube. The tuke was treated with a bit of $6 \mathrm{~N}$ phosphoric acid to decompose the carbonate adsorbed on the filter, and then put in a desiccator containing phosphorus pentoxide in order to drive out the remained water and carbon dioxide under reduced pressure. After the treatments, the sample was ready for the determination of organic carbon by the wet oxidation method of VAN SLYKE and FOLCH (1940). The difference between the organic carbon at initial and at intervals determinations was reckoned as the mineralized carbon.

For the study of absorption spectra of plankton pigments, the plankton sample was filtered through a millipore filter with a $0.8 \mu$ pore size. The collected matter was macerated in 92 per cent aceton at dark place for 24 hours. The extract was submitted to measure the absorption spectra at interval waves from 400 to $700 \mathrm{~m} \mu$ using spectrophotometer. 


\section{Experimental results}

According to the results of the microscopical observations in the course of decomposition for $S$. costatum kept at the dark at $30^{\circ} \mathrm{C}$, the plankton was typically shown the morphological change and fading of the pigments. The points are outlined as follow. In general, the plankton cells suspended uniformly in the culture medium where they kept in good conditions for temperature, nutrients and light sources. These cells exhibited, as it is called, a normal morphological aspect. While, shutting off the light from light source, the plankton began to sink on the bottom of the bottle and change the external appearance of its cell, whose protoplasm and chloroplast were clearly deformed to aggregate at a few places in the cell (abnormal cell). After a few days, a part of the abnormal cell-wall was cleaved, and running out the cytoplasm from the cleavage, the gel cohered each of the cells in one group to form a gelatinous aggregate. Many kinds of putrefactive bacteria were grown on the aggregates, which served a favorable base for bacteria to decompose actively. The de-

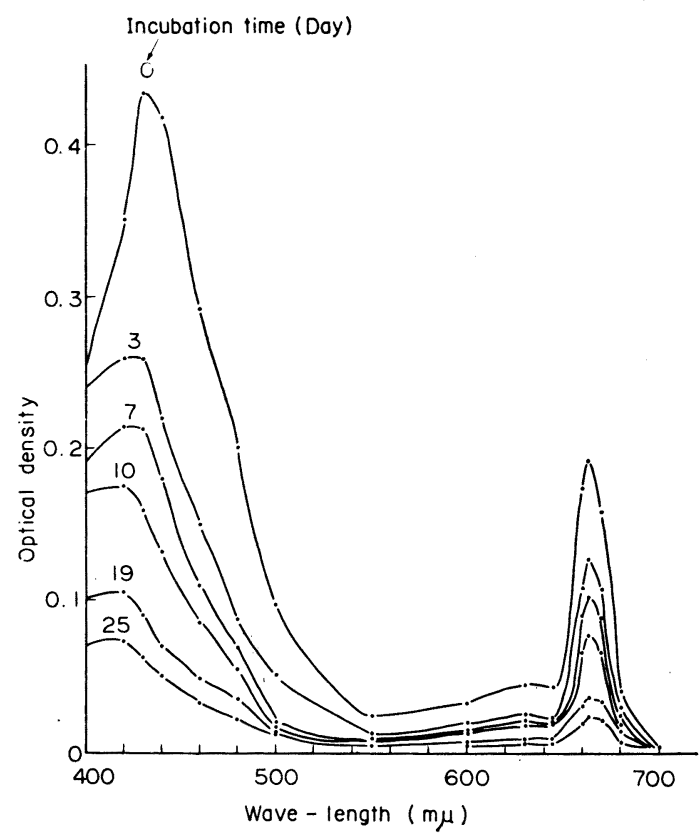

Fig. 1. Change in absorption spectra of phytoplankton pigments in the course of decomposition at dark. composition almost proceeded in the first fortnight. The aggregate, having brown color at early stage, has been allowed the transit to a fine yellow one, and also the amount of the aggregates remained after there was not remarkably decreased with the lapse of time. Then, the residual aggregates seemed to become more resistant to further decomposition, reaching an apparently constant level.

Fig. 1 shows an example of the disappearance patterns of plankton pigments during the course of decomposition in the dark. According to this figure, the absorption spectrum on the pigments has two peaks at 430 and $663 \mathrm{~m} \mu$ wave length at the starting sample. The former peak was shifted gradually to a more shorter wave length with the lapse of decomposition, but the place of the later one was not shifted visibly throughout the experimental period. The resemble disappearance configuration of the spectrum was observed also in the results when the same plankton sample kept in different temperature conditions, even though vary the rate of disappearance.

The amount of disappearance was calculated as per cent relative to the starting value of the absorption, which is illustrated in Fig. 2. The figure shows that the disappearance of each of the absorption peaks proceed at nearly same degree. On the experiments at $30^{\circ} \mathrm{C}$, each of the peaks was diminished about 80 per cent in the first 15 days, after then the diminution was not accepted so much degree. The residual part of the pigments reaching an apparently constant level was likely to be very resistant to further decomposition. On the other hand, it was not observed in the first one or two days that the pigments in the plankton stored at $10^{\circ} \mathrm{C}$ were so much faded or not as could have done the sample at $30^{\circ} \mathrm{C}$. But after then the both peaks diminished nearly in a straight line, which were disappeared respectively about 60 per cent at the end of experiments. From these experimental results, the disappearance rate of pigments in plankton was considered to be a function of temperature for the same sample.

It should be considered, in the same way, that temperature influenced upon the remineralization of inorganic nutrients from plankton. To pursue 

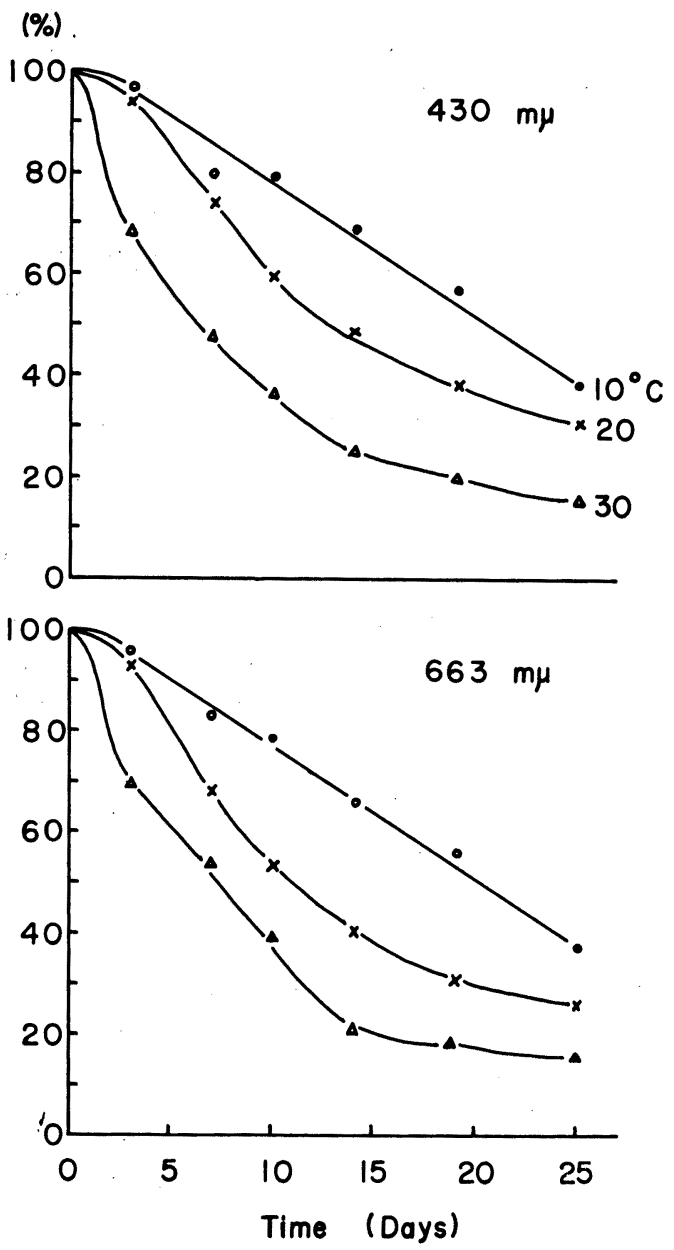

Fig. 2. Disappearance degree of the absorption peaks in the phytoplankton pigments ( $S$. costatum).

this point further, the plankton population cultured under the same conditions was separated into three parts, and each of them was stored at a dark cabinet thermostated at $10^{\circ}, 20^{\circ}$, and $30^{\circ} \mathrm{C}$, respectively. After darking, subsamples were periodically with drawn for the analysis of inorganic nutrients liberated from the plankton decomposing. The analytical results are shown in Table 1 and illustrated in Fig. 3. At the condition of $30^{\circ} \mathrm{C}$, about 70 per cent of phosphorus, nitrogen, carbon and silicon in the plankton were mineralized in the first 10 days. At the end of experiments, about 80 per cent in those of the plankton components was mineralized. At the early period kept at
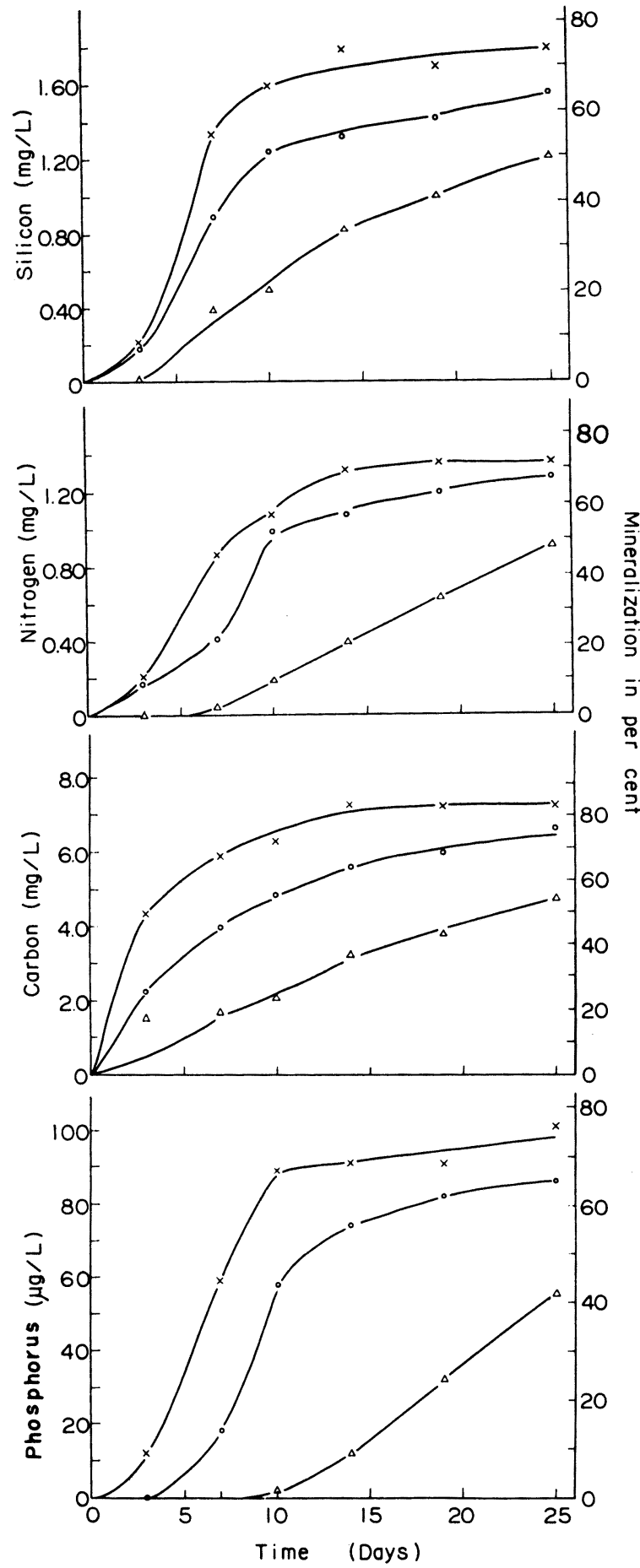

Fig. 3. Regeneration of inorganic nutrients in the course of mineralization at different temperature conditions. 
$10^{\circ} \mathrm{C}$, comparing with the experimental results at $30^{\circ} \mathrm{C}$, the liberation of silicon and the mineralizatization of carbon in the plankton get earlier than that of phosphorus and nitrogen. But at the final day of the experiments, phosphorus was mineralized only about 40 per cent from the plankton, and carbon, nitrogen and silicon about 50 per cent, respectively. From these experimental results, it could be interpreted that the start of death and decomposition of the plankton attending with inorganic nutrients exhaustion were influenced clearly by the temperature condition under which they were kept, and that the conspicuous loss of organic carbon during the early period kept at dark would be related to the respiratory consumption of stored carbohydrate and/or fat.

The ratios of carbon, nitrogen and silicon related to phosphorus are shown in Table 1 , in which the elements were mineralized in the course of plankton decomposition. At the early period kept at dark, the ratio of $\mathrm{C}: \mathrm{P}$ was generally higher than that in the starting plankton sample. The general tendency was also observed in the ratios of $\mathrm{N}: \mathrm{P}$, and $\mathrm{Si}: \mathrm{P}$, which was remarkable for the sample kept at $10^{\circ} \mathrm{C}$ as compared with the $30^{\circ} \mathrm{C}$.

In the preliminary works, it was observed that the proportions of elementary compositions in plankton $(\mathrm{N}: \mathrm{P}, \mathrm{Si}: \mathrm{P})$ were approached steadly to those of the medium when either nitrogen or phosphorus source became depleted. Hence, $S$. costatum was cultivated respectively in the three media, differing the concentration of inorganic nutrients and the ratios. A few days after the exhaustion of phosphate in the medium, a part of the plankton sample was used for the analysis of the elementary compositions. According to the analytical results as shown in Table 2 , the ratios of $\mathrm{N}: \mathrm{P}$, and $\mathrm{Si}: \mathrm{P}$ in the plankton sample were in good agreements with those ratios in which the inorganic nutrients source contained

Table 1. Regenration of inorganic nutrients from $S$. costatum at different temperature conditions.

\begin{tabular}{|c|c|c|c|c|c|c|c|}
\hline $\begin{array}{l}\text { Time } \\
\text { (Day) }\end{array}$ & $\begin{array}{l}\text { Phosphate } \\
(\mu \mathrm{g}\lceil l)\end{array}$ & $\begin{array}{c}\text { Carbon } \\
(\mathrm{mg} \mathrm{C} / \mathrm{l})\end{array}$ & $\begin{array}{l}\text { Nitrogen* } \\
(\mathrm{mg} \mathrm{N} / l)\end{array}$ & $\begin{array}{c}\text { Silicate } \\
(\mathrm{mg} \mathrm{Si} / l)\end{array}$ & $\mathrm{C} / \mathrm{P}$ & $\mathrm{N} / \mathrm{P}$ & $\mathrm{Si} / \mathrm{P}$ \\
\hline \multicolumn{8}{|l|}{$10^{\circ} \mathrm{C}$} \\
\hline 3 & 0 & 1.49 & 0 & 0 & - & 0 & 0 \\
\hline 7 & 0 & 1.66 & 0.04 & 0.38 & - & - & - \\
\hline 10 & 2 & 2.05 & 0.10 & 0.48 & 1025 & 95 & 245 \\
\hline 14 & 12 & 3.23 & 0.39 & 0.82 & 269 & 32.5 & 68.2 \\
\hline 19 & 32 & 3.83 & 0.63 & 1.00 & 200 & 19.7 & 31.3 \\
\hline 25 & 55 & 4.76 & 0.91 & 1. 21 & 86.5 & 16.5 & 22.0 \\
\hline \multicolumn{8}{|l|}{$20^{\circ} \mathrm{C}$} \\
\hline 3 & 0 & 2.22 & 0.18 & 0.29 & - & - & - \\
\hline 7 & 17 & 3.99 & 0.41 & 0.89 & 353 & 24.1 & 52.4 \\
\hline 10 & 58 & 4.86 & 0.99 & 1.24 & 83.8 & 17.1 & 21.4 \\
\hline 14 & 74 & 5.58 & 1.08 & 1. 32 & 75.4 & 14.6 & 17.8 \\
\hline 19 & 82 & 6.02 & 1.20 & 1.42 & 73.4 & 14.6 & 17.3 \\
\hline 25 & 86 & 6.65 & 1.28 & 1.56 & 77.3 & 14.9 & 18.1 \\
\hline \multicolumn{8}{|l|}{$30^{\circ} \mathrm{C}$} \\
\hline 3 & 12 & 4. 36 & 0.21 & 0.21 & 363 & 17.5 & 17.5 \\
\hline 7 & 59 & 5.89 & 0.86 & 1.33 & 99.8 & 14.6 & 22.5 \\
\hline 10 & 88 & 6.30 & 1,08 & 1.59 & 71.6 & 12.3 & 18.1 \\
\hline 14 & 91 & 7.27 & 1.32 & 1.79 & 79.9 & 14.5 & 19.7 \\
\hline 19 & 91 & 7.26 & 1.36 & 1.69 & 79.8 & 14.9 & 18.6 \\
\hline 25 & 101 & 7.28 & 1.36 & I. 79 & 72.1 & 13.5 & 17.7 \\
\hline \multicolumn{8}{|c|}{ Plankton components } \\
\hline & 133 & 8.86 & 1.90 & 2.43 & 66.4 & 14.3 & 18.3 \\
\hline
\end{tabular}

* Nitrogen is shown the amount of ammonia, nitrite and nitrate. 
Table 2. Regeneration of inorganic nutrients from $S$. costatum cultured at different medium conditions $\left(30^{\circ} \mathrm{C}\right)$.

\begin{tabular}{|c|c|c|c|c|c|}
\hline $\begin{array}{l}\text { Time } \\
\text { (Day) }\end{array}$ & $\begin{array}{l}\text { Phosphate } \\
(\mu \mathrm{g} \mathrm{P} / l)\end{array}$ & $\begin{array}{l}\text { Nitrogen* } \\
\text { (mg N/l) }\end{array}$ & $\begin{array}{c}\text { Silicate } \\
(\mathrm{mg} \mathrm{Si} / l)\end{array}$ & $\mathrm{N} / \mathrm{P}$ & $\mathrm{Si} / \mathrm{P}$ \\
\hline \multicolumn{6}{|c|}{ Experiment 1} \\
\hline 2 & 0 & 0.40 & 0.65 & - & - \\
\hline 5 & 73 & 1.03 & 0.95 & 14.4 & 13.1 \\
\hline 6 & 87 & 1.13 & 1.05 & 14.4 & 12.0 \\
\hline 7 & 104 & 1.18 & 1.07 & 11.3 & 10.3 \\
\hline 12 & 118 & 1.40 & 1.14 & 11.9 & 10.3 \\
\hline 15 & 122 & 1.40 & 1.18 & 11.5 & 9.7 \\
\hline \multicolumn{6}{|c|}{ Experiment 2} \\
\hline 2 & 0 & 0.30 & 0.53 & - & - \\
\hline 5 & 126 & 0.67 & 0.73 & 5.3 & 5.8 \\
\hline 6 & 152 & 0.70 & 0.80 & 4.6 & 5.3 \\
\hline 7 & 152 & 0.73 & 0.88 & 4.8 & 5.8 \\
\hline 12 & 169 & 0.86 & 0.89 & 5.1 & 5.3 \\
\hline 15 & 181 & 0.92 & 0.95 & 5.2 & 5.3 \\
\hline 17 & 182 & 0.94 & 0.93 & 5.2 & 5.1 \\
\hline \multicolumn{6}{|c|}{ Experiment 3} \\
\hline 2 & 0 & 0.09 & 0.50 & - & - \\
\hline 5 & 52 & 0.54 & 1.20 & 10.4 & 23.0 \\
\hline 6 & 82 & 0.63 & 1.30 & 7.4 & 15.8 \\
\hline 7 & 101 & 0.84 & 1.39 & 8.3 & 13.7 \\
\hline 12 & 124 & 0.89 & 1.50 & 7.2 & 12.1 \\
\hline 15 & 127 & 0.94 & 1.60 & 7.4 & 12.6 \\
\hline 17 & 127 & 1.03 & 1.79 & 8.0 & 13.9 \\
\hline \multicolumn{6}{|c|}{ Plankton components } \\
\hline Exp. 1 & 152 & 1.68 & 1.60 & 11.0 & 10.5 \\
\hline Exp. 2 & 250 & 1.32 & 1.48 & 5.3 & 5.8 \\
\hline Exp. 3 & 160 & 1.42 & 2.34 & 8.9 & 14.6 \\
\hline \multicolumn{6}{|c|}{ Medium components } \\
\hline Exp. 1 & 152 & 2.15 & 1.70 & 14.2 & 11.2 \\
\hline Exp. 2 & 250 & 1.32 & 1.55 & 5.3 & 6.2 \\
\hline Exp. 3 & 160 & 1.53 & 2.44 & 9.6 & 15.2 \\
\hline
\end{tabular}

* Nitrogen is shown the amount of ammonia, nitrite and nitrate.

in the culture medium at initial. The other part of the plankton sample was kept in a dark cabinet thermostated at $30^{\circ} \mathrm{C}$, and the inorganic nutrients liberated from this sample were periodically analyzed. The results are indicated in Table 2. According to the experimental results, the ratios of $\mathrm{N}: \mathrm{P}$, and $\mathrm{Si}: \mathrm{P}$ were almost constant in the course of mineralization, and also they were essentially identical with the ratios of the starting plankton. On the basis of these experimental results, it could be concluded that if one element is markedly deficient in the medium in which plankton grow, the composi- tion of the culture medium is clearly reflected in the elementary composition of the plankton cultivated under these conditions, and that the composition of the plankton regulates the remineralized elementary composition.

The mineralization rate seems to be affected not only by the temperature under which the sample was kept, but also by the species. Then, Thalassiosira decipiens (GRUN.) J $\phi$ RGENSEN and Chaetoceros gracilis SCHUTT were chosen for the following experiments to compare with the decomposition of $S$. costatum. The former two kinds of plankton cultivated at the 
Table 3. Regenration of inorganic nutrients from decomposing Ch. gracilis in the course of mineralization $\left(30^{\circ} \mathrm{C}\right)$.

\begin{tabular}{cccccc}
\hline $\begin{array}{c}\text { Time } \\
(\text { Day })\end{array}$ & $\begin{array}{c}\text { Phosphate } \\
(\mu \mathrm{g} \mathrm{P} / l)\end{array}$ & $\begin{array}{c}\text { Nitrogen* } \\
(\mathrm{mg} \mathrm{N} / l)\end{array}$ & $\begin{array}{c}\text { Silicate } \\
(\mathrm{mg} \mathrm{Si} / l)\end{array}$ & $\mathrm{N} / \mathrm{P}$ & $\mathrm{Si} / \mathrm{P}$ \\
\hline 2 & 0 & 0 & 0.57 & - & - \\
5 & 14 & 0 & 1.43 & - & 102 \\
8 & 21 & 0 & 1.70 & 12.1 & 81.0 \\
12 & 39 & 0.47 & 1.95 & 12.1 & 50.0 \\
16 & 75 & 0.70 & 2.15 & 9.3 & 32.0 \\
19 & 99 & 0.87 & 2.40 & 8.7 & 24.3 \\
26 & 127 & 1.12 & 2.43 & 8.8 & 19.2 \\
32 & 152 & 1.38 & 2.51 & 9.1 & 16.6 \\
\hline \multicolumn{2}{l}{ Plankton components } & & & & \\
\multicolumn{2}{l}{} \\
214 & 2.50 & 3.30 & 11.7 & 15.4 \\
\hline
\end{tabular}

* Nitrogen is shown the amount of ammonia, nitrite and nitrate.

Table 4. Regeneration of inorganic nutrients from decomposing $T$. decipiens in the course of mineralization $\left(30^{\circ} \mathrm{C}\right)$.

\begin{tabular}{cccccc}
\hline $\begin{array}{c}\text { Time } \\
(\text { Day })\end{array}$ & $\begin{array}{c}\text { Phosphate } \\
(\mu \mathrm{g} \mathrm{P} / l)\end{array}$ & $\begin{array}{c}\text { Nitrogen* } \\
(\mathrm{mg} \mathrm{N} / l)\end{array}$ & $\begin{array}{c}\text { Silicate } \\
(\mathrm{mg} \mathrm{Si} / l)\end{array}$ & $\mathrm{N} / \mathrm{P}$ & $\mathrm{Si} / \mathrm{P}$ \\
\hline 3 & 0 & 0 & 0 & - & - \\
6 & 0 & 0 & 0.08 & - & - \\
10 & 0 & 0 & 0.25 & - & - \\
13 & 0 & 0 & 0.50 & - & - \\
17 & 0 & 0 & 0.69 & - & 130 \\
22 & 10 & 0.08 & 1.30 & 8.5 & 80.0 \\
27 & 19 & 0.22 & 1.52 & 11.3 & 34.7 \\
34 & 61 & 0.62 & 2.13 & 10.2 & 28.9 \\
40 & 79 & 0.85 & 2.29 & 10.8 & 25.0 \\
48 & 98 & 0.93 & 2.49 & 9.5 & 22.2 \\
52 & 115 & 1.32 & 2.55 & 11.4 & \\
\hline \multicolumn{2}{l}{ Plankton components } & & & & 16.9 \\
\hline
\end{tabular}

* Nitrogen is shown the amount of ammonia, nitrite and nitrate.

same conditions mentioned above and submitted to the decomposition in dark cabinet thermostated at $30^{\circ} \mathrm{C}$. The experimental results are indicated in Tables 3 and 4 . From these results, it was observed as one of typically different aspects that these plankters were seriously delayed the start of mineralization, particularly in phosphorus and nitrogen, comparing with the mineralization of $S$. costatum. At the early stage in the course of mineralization, the silicate liberated itself from the plankton without a comparing mineralization in phosphorus and nitrogen. Hence, the ratio of $\mathrm{Si}: \mathrm{P}$ showed typically high value at the early time in the course of minerali- zation, but as the mineralization went on the ratio was gradually decreased and approached to the value in which the plankton sample had a initial. Meanwhile, the $\mathrm{N}: \mathrm{P}$ ratio maintained nearly constant value and was close to the ratio in the starting plankton sample.

It may be inferred from the above experimental results, regardless of any difference in bacteria community attacking the plankton, that in the dark, the duration of plankton survival is generally different with species, that the resolution of silicate from the diatom wall reflects the time of lossing the normal activity, and also that the liberation of inorganic phosphate and 


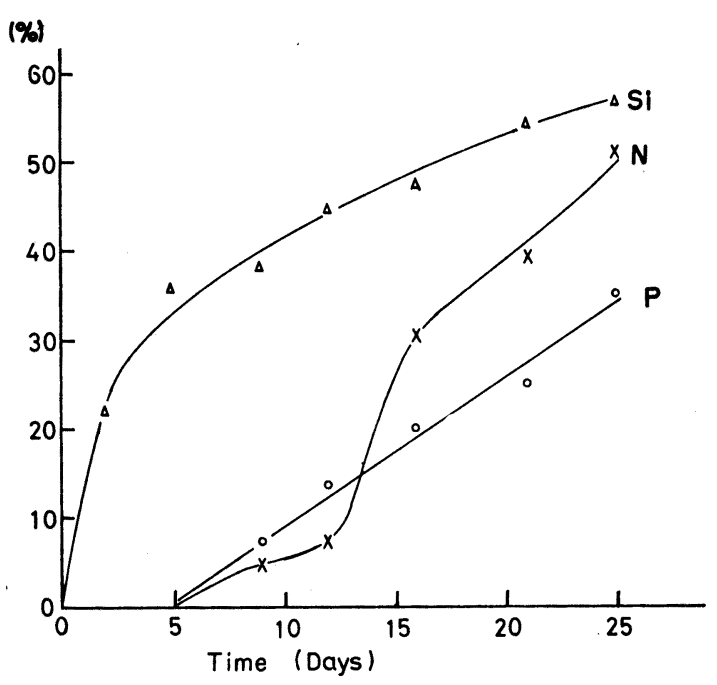

Fig. 4. Regeneration of inorganic nutrients from the morphorogically changed plankton community in the course of mineralization.

ammonia are shown the death.

It would be presumed, next, that the physiological conditions of plankton have an effect on the decomposition rate. To pursue this piont further, the following scheme was carried out by using $S$. costatum cultured with the methods mentioned above. The plankton sample, when the inorganic nutrients in the medium were exhausted, was transferred into a polyethylene bottle, and kept under the dim-light condition in a corner of laboratory for 7 days. In this case, the plankton community began to settle on the bottom of the bottle one or two days later, and also it was observed by the microscopic examination that almost of the plankton colonies changed morphologically to extent that their species could not be recognized. The silica-wall of the plankton began to redissolve silicate without a corresponding liberation of inorganic phosphate and ammonia. After the 7-day storage, the plankton sample was transfered into a dark cabinet thermostated at $30^{\circ} \mathrm{C}$ for the study of the decomposition. The experimental results are shown in Fig. 4, in which each element liberated from plankton was illustrated in percentage in regard to those in the starting plankton. The following points were different from the illustrations as shown in Fig. 3: (1) the morphologically changed plankton was used longer time to begin the start of the minerali- zation of nitrogen and phosphorus, and (2) the mineralization rate showed a slower pace. In view of the above facts, it seems more reasonable to consider that the morphological change of plankton provides them a resistance power against the bacterial attack and also uncofortable conditions.

\section{Discussion}

According to the present experimental results, the mineralization processes can be briefly divided into four stages, i.e. (1) the plankton sinking on the bottom and the morphological change, (2) the liberation of silicate, ammonia and phosphate, (3) the liberated ammonia oxidize to nitrite, and then (4) to nitrate. In the processes, almost of the decomposable parts of nitrogen, phosphorus and silicon in the plankton body set free into the medium at the first stage, which was regulated by physiological characters and species of diatom, and also by temperature condition. About 70 to 80 per cent of the plankton components seemed to be labile parts. This interpretation was in good agreement with those reported by COOPER (1935) and VON BRAND et al. (1937, 1942). The residual part of the starting plankton is likely to be changed itself into marine humus, bacteria or water soluble organic matters in the system, reaching an apparently constant level.

From the considerations of the experimental results presented in this report and of the diatom sinking rates calculated by SMAYDA and BOLEYN $(1965,1966 \mathrm{a}, \mathrm{b})$, it seems most reasonable to infer that the mineralization of the labile part of plankton might be taken place in the upper several hundreds meters depth, even if physical factors, such as vertical circulation and current, have influence upon the sinking rate of plankton, and also the environmental temperature regulates bacteria- and enzym- activities affecting upon the decomposition rate.

Chlorophyll a, b and c concentration in sea water samples has been used to estimate the biomass and the photosynthetic capacity of phytoplankton, while the pigment ratio $\left(\mathrm{D}_{\mathbf{4 3 0}} /\right.$ $\mathrm{D}_{665}$ ) between the optical density of extracts in 90 per cent aceton, at 430 and $665 \mathrm{~m} \mu$, has been used for the study of the physiological state of 
the community (IIZUKA et al., 1960, 1961; IIZUKA, 1963). IIZUKA observed that the absorption peak at $435 \mathrm{~m} \mu$ shifted to more shorter wave length, and also that the pigment ratio in the plankton increased steadily according to the progress of day spent for preservation. YENTSCH and RYTHER (1959) recognized that the absorption curves of aceton extracts of particulate matter from deepwater samples showed a disappearance of the red peak of chlorophyll a. Basically, it should be considered that chlorophyll $a$ is more quickly decomposed than other pigments in plankton. In the present study, it was observed that there is a shifting of the blue absorption peak from about 435 to $410 \mathrm{~m} \mu$ and some evidence of a small shifting to longer wave length of the peak at $665 \mathrm{~m} \mu$. No clear evidence was, however, observed on the increasing of the pigment ratio in the course of mineralization.

It is well known that the pigment ratio in plankton fluctuates over a wide range by their physiological conditions and also as the results of their digestion by the guts of plankton herbivorous. Example of this can be seen in the review of MAGALEF (1967). The author (1968) observed that the absorption curves of the acetone extracts showed a more confirmatory change by the passage of phytoplankton through the guts of plankton herbivorous than that of the case in which the plankton was mineralized only in the presence of bacteria community in dark place. However, there was no clear evidence indicating what kind of pigments in plankton were easily disappeared and/or changed to its derivatives. It is desirable to extend this work to a quantitative examination of plankton pigments and to the determination of the particular pigments degradations products in the course of decomposition.

The ratios of principal elements presented in plankton were markedly affected by changing those ratios of the medium in which they grew, and also appeared to be differed in species. In ocean, the concentration of available inorganic nutrients and these ratios are greatly varied not only from one water mass to another, but also from season to season. On the other hand, the concentration of available nitrogen and phosphorus resources in the open sea are reduced to trace amounts when phytoplankton community blooming at active. It is an wellknown fact that there is a localization of plankton species in the sea. From all these observations, it would be presumed consequently that the nitrogen: carbon: silicon: phosphorus ratios in the plankton comunity, and in a water mass are inevitably varied. As result, the anomaly of nitrate-phosphate ratio as pointed out by COOPER (1937) might be appeared among the different water masses, and then the anomaly would be reflected upon the components of the plankton community.

At the early stage of the decomposition, the typical disappearance of organic carbon in $S$. costatum could be understood as an evidence that the carbohydrate and fat reserved in the body are consumed dominantly by the respiration. If oxygen dissolved in the medium was consumed stoichiometrically for the oxidation of the organic carbon to carbon dioxide in the early stage of mineralization, it could not be established here the hypothesis "Apparent Oxygen Utilization" proposed by REDFIELD (1934), which shows the simple relationships between the consumption of oxygen from sea water, the regeneration of inorganic phosphate and nitrate, and the composition of plankton organisms. There is some assertion that in the euphotic zone zooplankton excrete considerable amount of inorganic nutrients into sea water as the metabolic products than that done by the bacterial decomposition (HARRIS, 1959). In the shallow layer, the condition of biological oxygen balance is distorted by the air-sea interchange of oxygen. Hence, to clear up the hypothesis "AOU" in situ, it is necessary to study systematiccally the correlation between the oxygen consumption, and the excretion of ammonia, phosphate and carbon dioxide by zooplankton populations, in addition to the oxygen diffusion by the vertical movements of water at certain depth.

It was recognized, at the early stage of the mineralization, that the silica-wall of diatom used in the present study began to dissolve silicate into the medium before the liberation of ammonia and phosphate took place. If the silica-wall of diatom is protected from sea water by an organic skin (COOPER, 1952), the skin, though it was not identified by chemical analysis, should likely 
be unstable for the biological attack. The temperature-solubility curve indicates that the solubility of amorphous silica in sea water is in the range of $50-100 \mathrm{mg}$ per liter (KRAUSKOPF, 1959; SIVER, 1962). The silica concentration in the oceans are very low, usually less than $0.5 \mathrm{mg}$ per liter at surface waters and maximum of 5 $\mathrm{mg}$ in deep waters. The dissolution of solid silica in water involves a simultaneous hydration and depolymerization, catalyzing by base and salts (ILER, 1955). The dissolution rate of diatom frustule in sea water was faster than in distilled water (KAMATANI, 1968). It would be generally considered from the above mentioned facts that the delicate siliceous frustules of diatoms were exposed to such a condition suitable for the dissolving. Then, some species, as used in the present examination, form their frustules so delicate that they dissolve soon after the death of the organisms.

Diatomaceaus earth and diatom ooze, however, are present actually on the earth at places where the skeletone of diatoms have retained through geological ages the geometrical regularity of the structure of the living cell unchanged. If the silica-walls of all kinds of diatoms have a soluble character for sea water as obtained in the present study, it will be proposed a problem why diatom ooze and diatomaceaus earth are present on the earth.

ILER (1955) has speculated that the magnesium, iron, aluminum, or other polyvalent cations in natural water may produce a coating of insoluble silicates. LEWIN (1961) cleared up experimentally that certain metal ions (mainly $\mathrm{Fe}$, $\mathrm{Al}, \mathrm{Mn}$ ) under specific conditions combing with the silica walls of diatoms, affected either their subsequent rate of dissolution or their final solubility. In view of the actual fact, the concentration of iron, manganes and aluminum in sea water are very low to combine with the silica walls of diatoms, so that these concentration would not behave as an negative factor for the dissolution rate. If those polyvalent cations in sea water are reacted equally with the silica walls of every diatom genera, it might not be appeared such an uneven distribution as mentioned below. The assemblage of diatom frustules found from the $3,000 \mathrm{~m}$ depth is only one per cent of that from the surface water, varing the community (OSHITE, 1968). The diatom assemblages of the plankton and of the sediments are quite different in community (CALVERT, 1966), and also except for few species, frustules of the cell of Chaetoceros and Rhizosolenia are rarely found in bottom sediments, despite the fact that these genera are represented in plankton by large numbers of species and in dividuals (KANAYA and KoIZUMI, 1966). How long the diatoms keep alive during their sinking from the photic zone to the sea floor may regulate the sinking rate and also the dissolution rate of the silica frustules, in turn, influence the diatom assemblage of the sediments.

The frustules of diatoms buried in marine sediments might have more opportunities to contact with iron, aluminum and other polyvalent cations, or humic acid influencing upon the solubility in sea floor than in sea water, because the concentration of these cations and humic acid in sediments are of several millions times than in sea water. Then, the silica frustules buried in the sediments combine with some polyvalent cations and change to unsoluble form. In the sense of geological years, on the other hand, ROGALL (1939) obtained some evidence by the examination with X-ray diffraction methods that the silica frustules of diatoms changed to crystalline form. It is proposed an interesting question why the amorphous silica of diatom wall gradually changed to a crystalline form in the geological years.

\section{Acknowledgements}

The author is grateful to Professor C. MAtsuDAIRA for his unfailling guidance throughout the course of this work and Dr. Y. MORITA for his helpful suggestion.

\section{References}

Von Brand, T., N. W. Rakestraw and C. E. RENN (1937): The experimental decomposition and regeneration of nitrogenous organic matter in sea water. Biol. Bull., 72, 165-175.

VON BRAND, T. and N. W. RAKESTRAW (1937-47): Decomposition and regeneration of nitrogeneous organic matter in sea water. 1-VI. Biol. Bull., 72, 77, 79, 83, and 92.

CAlvert, S. E. (1966): Accumulation of diato- 
maceous silica in the sediments of the Gulf of California. Geol. Soc. Amer. Bull., 77, 569-596.

COOPER, L. H. N. (1935): The rate of liberation of phosphate in sea water by the breakdown of plankton organisms. J. Mar. Biol. Assoc. U.K., 20, 197-202.

COOPER, L. H. N. (1937): On the ratio of nitrogen to phosphorus in the sea. J. Mar. Biol. Assoc. U.K., 22, 177-204.

COOPER, L. H. N. (1952): Factors affecting the distribution of silicate in the North Atlantic Ocean and the formation of North Atlantic deep water. J. Mar. Biol. Ass. U.K., 30, 511-526.

FLEMING, R. H. (1940): The composition of plankton and unit for reporting population and production. Proc. Sixth Pacific Sci. Cong. Calif., 1939, 3, 535-540.

GRILl, E. V. and F. A. Richards (1964): Nutrients regeneration from phytoplankton decomposing in sea water. J. Mar. Res., 22, 51-69.

HARRIS, E. (1959): The nitrogen cycle in Long Island Sound. Bull. Bingham Oceanog. Coll., 17, 31-65.

IIzUKA, S., T. SimizU, T. KazIhara, and H. IRIE (1960): Spectrophotometric investigation of the plankton pigments 11 . On the daily variation of the pigment amount. Bull. Fac. Fish. Nagasaki Univ., 9, 59-63.

IIZUKA, S. and H. IRIE (1961): Spectrophotometric investigation of the plankton pigment 111 . Relations between pigment amount and cell number of phytoplankton. Bull. Fac. Fish. Nagasaki Univ., 10, 211-216.

IrzUKA, (1963): Depression of activity of the phytoplankton preserved in dark conditon and the abnormal types of spectral absorption curve as its results. Bull. Fac. Fish. Nagasaki Univ., 15, 100-115.

ILER, R. K. (1955): The colloid chemistry of silica and silicates. Cornell. Univ. Press, Ithaca, N.Y..

JoRGENSEN, E. G. (1955): Solubility of the silica in diatoms. Physiol. Planta, 8, 846-851.

Kamatani, A. (1968): Thesis, Tohoku University.

KANAYA, T. and I. KoIZUMI (1966): Interpretation of diatom thanatocoenoses from the North Pacific

applied to a study of core V 20-130 (Studies of a deep-sea core V 20-130 Part IV). Sci. Rep. Tohoku Univ., 2d ser. (Geol), 37, 89-130.

Ketchum, B. H. and A. C. Redfield (1949): Some physical and chemical characteristics of algae grow in mass culture. J. Cell. Comp. Physiol., 2, 172 $-181$.

Krauskopf, K. B. (1959): The geochemistry of silica in sedimentary environments. In: Silica in sediments; Soc. Econ. Paleontologists \& Mineralogists Special Pub., 7, 4-19.

LEWIN, J. C. (1961): The dissolution of silica from diatom walls. Geochim. Cosmochim. Acta, 21, 182-198.

MAGALEF, R. (1967): Some concepts relative to the organization of plankton. Oceanogr. Mar. Biol. Ann. Rev., 5, 257-289.

Morris, A. W. and J. P. RILeY (1963): The determination of nitrate in sea water. Anal. Chim. Acta, 29, 272-279.

Menzel, D. W. and N. CoRWIN (1965): The measurement of total phosphorus in seawater based on the liberation of organic bound fractions by persulfate oxidation. Limnol. Oceanogr., 10, 280-282.

MurPhy, J. and J. P. RILEy (1962): A modified single solution method for the determination of phosphate in natural waters. Anal. Chim. Acta, 27, 31-36.

OsHITE, K. (1968): Suspended matters. Rep. 3rd Antarc. Exp., 1964-1965. J. Tokyo Univ. Fish. (Sp. Edition) 9(2), 5-25.

Rogall, E. (1939): Uber den Finbau der Kieselmenbran der Diatommen. Planta, 29, 279-291.

REDFIELD, A. C. (1934): On the proportions of organic derivatives in sea water and their relation to the composition of plankton. James Johnstone Memorial Vol., Univ. Press, Liverpool, pp. 176192.

RichardS, F. A. (1958): Dissolved silicate and related properties of some western North Atlantic and Caribbean waters. J. Mar. Res., 17, 449465.

Riley, J. P. and G. SkIRrow (1965): Chemical Oceanography Vol. 1, pp. 323-430, Academic Press, London and New York.

Robinson, R. J. and T. G. Thompson (1948): The determination of silicate in sea water. J. Mar. Res., 7, 49-55.

SIVER, R. (1962): Silica solubility, 0-200 C, and the diagenesis of siliceous sediments. J. Geol., 70, $127-150$

SMAYDA, T. J. and B. J. BoleYN (1965, 1966a, 1966b): Experimental observations on the flotation of marine diatoms I, II, III. Limnol. Oceanogr., 10, 499-509, 11, 18-34, 11, 35-43.

VAN Slyke, D. D. and J. Folch (1940): Manometric carbon determination. J. Biol. Chem., 136, 509-541.

YentsCh, C. S. and J. H. Ryther (1959): Absorption curves of acetone extracts of deep water particulate matter. Deep-Sea Res., 6, 72-74. 


\section{珠藻プランクトンからの無機栄養塩の再生}

鎌谷明善

要旨 培養した珪藻プランクトン ( S. costatum, $T$. decipiens, Ch. gracilis) を暗所に保存し, その分解過程 を研究した. 分解過程は 4 段階に大別され，珪藻体の易 分解性部分の分解は第 2 段階までにほぼ終了するようで あった. 分解速度は珪藻の生理条件, 種の違い, 及び保 存時の温度条件によって異なることがわかった．

珪藻体の珪酸の溶出と有機炭素の消失は, 分解初期に おいて燐と窒素の再生に先行するため, 再生した珪素と 燐の比は顕著に高かった. しかし分解が進むにつれ, 珪 素と燐の比は実験に供した初期の珪藻体の比に漸近し
た. 一方, 再生した窒素と燐の比は前者に見られるほど 大きな変動はなかった．しかしこれらの比もまた分解速 度と同様に生理条件とか温度条件に規定されるようであ った.なお珄酸款の溶解性については最後に二・三の考 察を加えた.

本研究結果を総合すると, 分解初期における見掛上の 酸素消費と再生した燐, 窒素及び珪 素の間には REDFIELD (1934) 及び RICHARDS (1958) が現場の解析から 得たような化学量論的な関係は成り立たないように推定 された. 